Contents List available at RAZI Publishing

Malaysian Journal of Sustainable Agriculture (MJSA)

Journal Homepage: http://www.razipublishing.com/journals/malaysian- journalof-sustainable-agriculture-mjsa/

https://doi.org/10.26480/mjsa.01.2017.04.07

\title{
WATER REQUIREMENTS FOR VARIOUS CROPS AND IMPACT OF IRRIGATION İN̄ BARIND AREA
}

\section{Md. Kumruzzaman a, Anirban Sarker b}

a Professor, b Undergraduate Research Scholar, Department of Civil Engineering, Rajshahi University of Engineering and Technology, Rajshahi-6204, Bangladesh.

This is an open access article distributed under the Creative Commons Attribution License, which permits unrestricted use, distribution, and reproduction in any medium, provided the original work is properly cited

\section{ARTICLE DETAILS}

Article history:

Received 12 August 2016 Accepted 12 December 2016

Available online 20 January 2017

Keywords:

Consumptive use, consumptive irrigation requirement, BlaneyCriddle Method.
ABSTRACT

In this paper successive depletion of groundwater level with expansion of ground water irrigation in Barind Tract has been discussed from 1985 to 2015 . Rajshahi is a city in western Bangladesh. It is located in the north-west part of the country and situated on the northern banks of the river Padma. After starting of groundwater irrigation in Bangladesh, it spread rapidly all over the country, and about $80 \%$ of agricultural land is now supplied irrigation from groundwater. This study was conducted to estimate the Consumptive use and Crop Irrigation Requirement for various crops like Amon(rice), Boro(rice), Wheat and Potato. Blaney-Criddle Method was used in this study. In this study, data was collected from the zonal office of Barind Multipurpose Development Authority (BMDA), Rajshahi and Bangladesh Meteorological Department, Meteorological complex, Green Road, Dhaka. From the data analysis, the maximum value of consumptive use is $27.88 \mathrm{~cm}$ in the month of April, 1989 and minimum value of consumptive use is $2.02 \mathrm{~cm}$ in the month of February, 2011. The maximum value of Crop Irrigation Requirement is $21.66 \mathrm{~cm}$ in 1987.

\section{INTRODUCTION}

In order to achieve sustainable agricultural growth and to maintain ecological balance under the Barind Multipurpose Development Authority (BMDA) was launched during late eighties century Chapai Nawabgang, Noagan and Rajshahi districts which includes 25 Upazillas (sub-district) in the 'Barind Area' at the north western part of Bangladesh covering an area of $7500 \mathrm{~km}^{2}$.[1] In this area there is limited scope to conserve rain water for irrigation and lack of modern agricultural technology resulted in agricultural and socio-economic backwardness.

Under Köppen climate classification [2] Rajshahi has a tropical wet and dry climate. The climate of Rajshahi is generally marked with monsoons, high temperature, considerable humidity and moderate rainfall. The hot season commences early in March and continues till the middle of July. The maximum mean temperature observed is about 32 to $36^{\circ} \mathrm{C}\left(90\right.$ to $\left.97^{\circ} \mathrm{F}\right)$ during the months of April, May, June and July and the minimum temperature recorded in January is about 7 to $16^{\circ} \mathrm{C}$ ( 45 to $61^{\circ} \mathrm{F}$ ). the highest rainfall is observed during the months of monsoon. The annual rainfall in the district is about 1,448 millimeters (57.0in).

Irrigation is the artificial application of water to the land or soil. It is used to assist in the growing of agricultural crops, maintenance of landscapes and re-vegetation of disturbed soils in dry areas and during periods of inadequate rainfall. Additionally, irrigation also has a few other uses in crop production, which include protecting plants against frost, suppressing weed growing in grain fields and helping in preventing soil consolidation.[3] In contrast, agriculture that relies only on direct rainfall is referred to as rain-fed or dry land farming. Irrigation systems are also used for dust suppression, disposal of sewage and in mining. Irrigation is often studied together with drainage, which is the natural or artificial

removal of surface and sub-surface water from a given area. [4]

Climate is the most important to decide the rate of evapotranspiration. Several empirical formulas are available to estimate evapotranspiration from climate data. FAO expert group of scientists has recommended four methods for adoption of different regions of world. Among all of these methods Penman Method provides more accurate result.[5] One of the practical application of estimation of evapotranspiration is in the design of irrigation system to meet the water demand of plant growth during the period of sufficient water.

Water is needed mainly to meet the demand of evaporation transpiration and metabolic needs of the planets, all together is known as consumptive use. . Since water used in the metabolic activities of plant is negligible, being only less than one percent of quantity of water passing through the plant, evaporation and transpiration, i.e. evaporation is directly considered as equal to consumptive use.[6] In addition to evapotranspiration, water requirement includes losses during the application of irrigation water to field (percolation, seepage and run off) and water required for special operation such as land preparation, transplanting, leaching etc. [7]

MacDonald (1978) studied that that transmissivity values of the aquifer ranges from $1000 \mathrm{~m} 2$ /day to $2000 \mathrm{~m} 2$ /day but it less than $1000 \mathrm{~m} 2 /$ day in Paba upazilla and average storage coefficient value was estimated 0.01. [8] Consequently ground water is being withdrawn from storage and water levels are declining resulting in crop failure adverse salt balance, sea waters intrusion in costal aquifers and subsidence in areas where draft resulting compaction of sediment. Even in high rainfall areas of the state, water scarcity is 
experienced in summer months [9].

The proper management of ground water resources requires an adequate knowledge of the extent of the storage, the rate of discharge, the rate of recharge to ground water body and the use of economical of extraction.[10] Ground water has been the source of irrigation in the agro based Barind area by installation of Deep Tube wells (DTWs) and Shallow Tube wells (STWs). At present the total cultivable area is about $0.58 \mathrm{~m}$-ha of which only $26 \%(0.58 \mathrm{mha})$ have been brought under irrigation by both surface and groundwater. Study also included analysis of available metrological data. [11]

The objectives of this study is to determine the consumptive use and crop irrigation requirement of the Barind area. The consumptive use and crop irrigation requirement is to be compared. Total irrigation water requirement is to be calculated by using Blaney-Criddle Method. The study helps to know the total amount of water that is required for crops during its base period, the maximum amount of irrigation water required for growing crops, the Fluctuation of ground water level in Barind area.

\section{STUDY AREA}

Rajshahi is a city in western Bangladesh and the divisional headquarters of Rajshahi Division as well as the administrative district that bears its name and is one of the seven metropolitan cities of Bangladesh. Silk of Rajshahi was of great quality once upon a time, so this city is often referred to as Silk City and Education City for its calm environment. Rajshahi is located in the north-west part of the county and has an estimated population of 853,000 people. Its tota area is $96.69 \mathrm{~km}^{2}$ (37.33 mile $)$ and it's situated on the northern banks of the river Padma (or Ganges which is one of the major rivers of the Indian subcontinent).

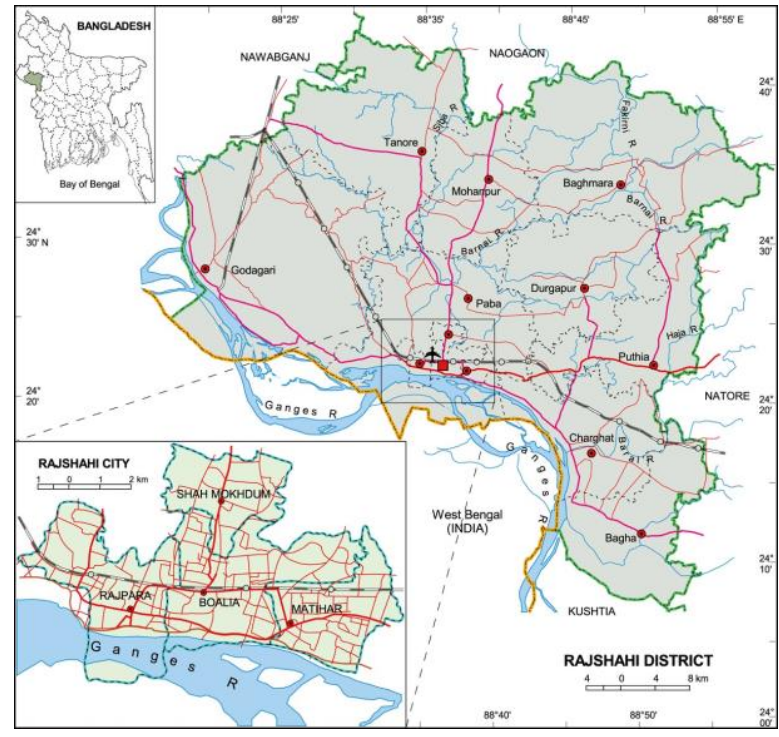

FIGURE 2.1: PHYSIOGRAPHIC MAP OF STUDY AREA

The hard red soil of this area is very significant in comparison to the other part of the county (BMDA). The Rajshahi district is located in between 24 degree 23 minute to 25 degree 15 minute north latitude and 88 degree 2 minute to 88 degree 57 minute east longitude.

\section{RESEARCH METHODOLOGY}

\subsection{Blaney-Criddle Method}

Blaney and Criddle (1950) observed that the amount of water consumptive use by

crops during their growing seasons was closely correlated with mean monthly temperature and day light hours and developed an empirical relationship stated as follows:

$\mathrm{Cu}=\frac{k \times P}{40} \quad[1.8 \mathrm{t}+32] \ldots$
$\mathrm{K}=$ Crop factor, determined from experiment for each crop and depends

upon the environmental condition of the area.

$\mathrm{P}=$ Monthly percentage of annual day light hours $\mathrm{T}=$ Mean monthly temperature in ${ }^{\circ} \mathrm{C}$

Let, $f=\frac{P}{40}[1.8 \mathrm{t}+32]$

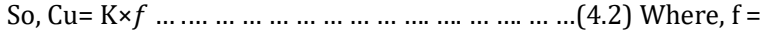
Summation of ' $f$ ' values during the crop season.

The above formula involves the use of crop factor, the value of which is to be

determined for each crop and for different places and now this information is not available in our country for different places and different crops. Moreover, this formula does not take into consideration the factors such as elevation wind velocity and humidity etc. on which consumptive use depends.

It is the amount of irrigation water required in order to meet the evapotranspiration

needs of the crop during its full growth. It is, therefore, nothing but the consumptive use itself, but exclusive of effective precipitation, stored soil moisture, or ground water. When the last two are ignored, then we can write,

C.I.R $=\mathrm{Cu}-\mathrm{Re}$

Total water requirement $=$ C.I.R $\times$ Area

\section{DATA COLLECTION}

Rainfall and static water level data collect from the zonal office of Barind Multipurpose

Development Authority (BMDA), Rajshahi. Temperature and monthly sun shine hour's data has been collected from Bangladesh Meteorological Department, climate division, Dhaka

\section{GRAPHICAL REPRESENTATION}

Monthly variation of Crop Irrigation Requirement(C.I.R) and Consumptive use $(\mathrm{Cu})$ for Amon

(rice) crops for maximum, minimum temperature are given from figure 5.1-5.4

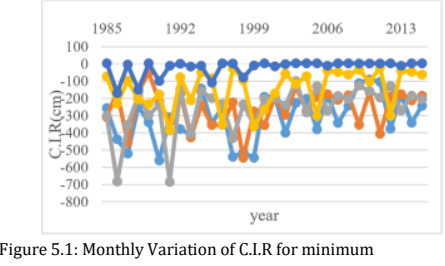

temperature for Amon (rice)
Figure 5.2: Monthly Variation of C.I.R for maximum

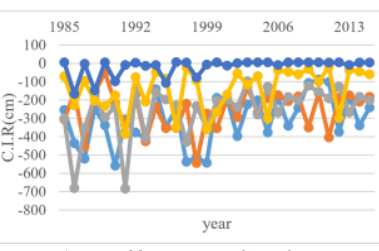

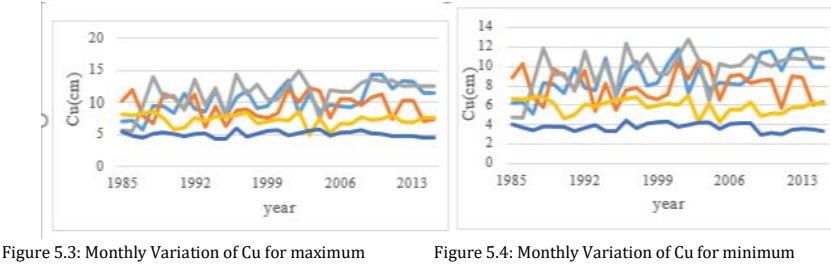

temperature for Amon(rice) 
Consumptive use $(\mathrm{Cu})$ for Boro

(rice) crops for maximum, minimum temperature are given from figure $5.5-5.8$

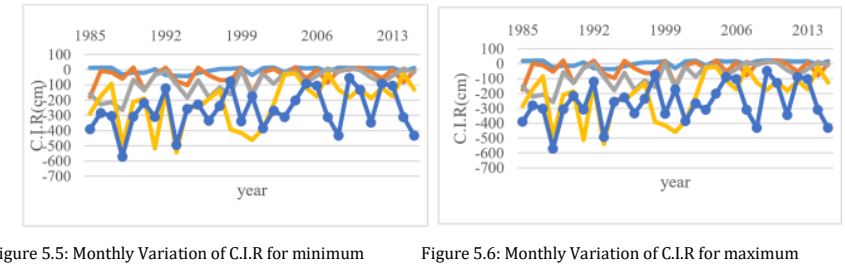

temperature for Boro (rice) temperature for Boro (RICE)

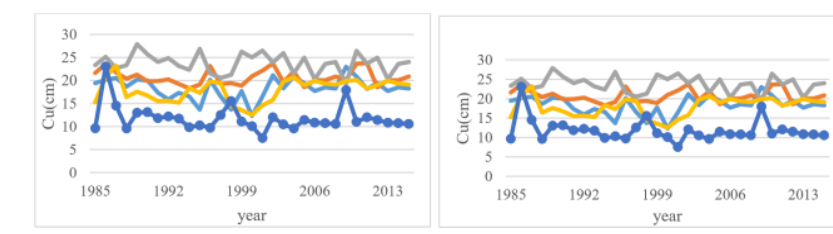

Figure 5.7: Monthly Variation of Cu for maximum

Figure 5.8: Monthly Variation of Cu for minimum

temperature for Boro (rice)

temperature for Boro (RICE)

Monthly variation of Crop Irrigation Requirement (C.I.R) and Consumptive use $(\mathrm{Cu})$ for Wheat crops for maximum, minimum temperature are given from figure 5.9-5.12
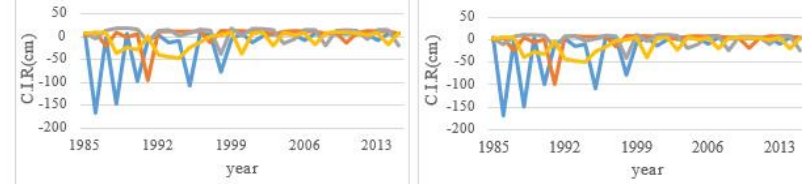

Figure 5.9: Monthly Variation of C.I.R for maximum

Figure 5.10: Monthly Variation of C.I.R for minimum

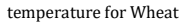

temperature for Wheat
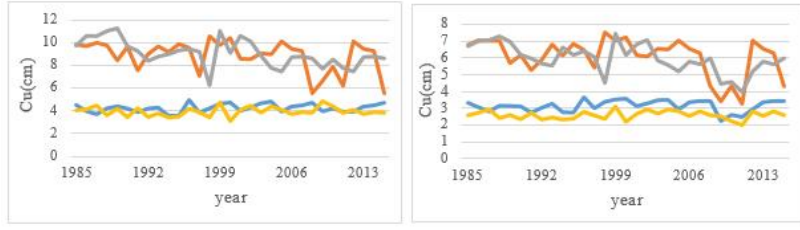

Figure 5.11: Monthly Variation of Cu for maximum

Figure 5.12: Monthly Variation of Cu for minimum

temperature for Wheat

temperature for Wheat
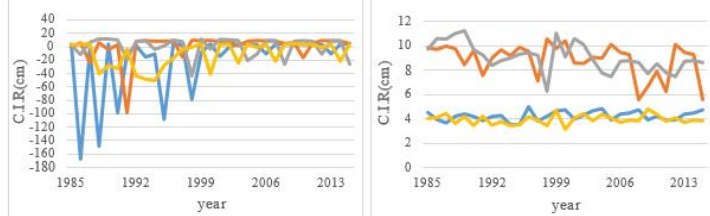

Figure 5.13: Monthly Variation of C.I.R for maximum

Figure 5.14: Monthly Variation of C.I.R for minimum

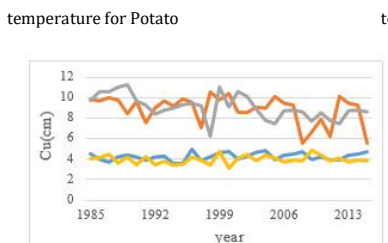

emperature for Potato

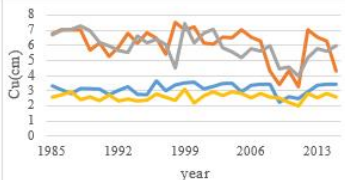

Figure 5.15: Monthly Variation of Cu for maximum

Figure 5.16: Monthly Variation of Cu for minimum

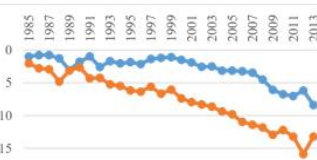

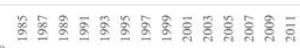

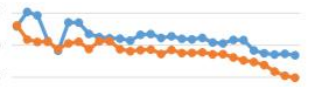

Figure 5.17: Yearly minimum groundwater depletion $\quad$ Figure 5.18: Yearly maximum groundwater depletion

rate of Boalia \& Tanore

rate of Boalia \& Tanore

\section{RESULTS AND DISCUSSION}

Crop water requirement from 1985 to 2015 in Barind area Rajshahi for Amon (rice) for average temperature is $558.8 \mathrm{~cm}$, for maximum temperature is $683.2 \mathrm{~cm}$ and for minimum temperature is $684.5 \mathrm{~cm}$. Maximum water requirement for Amon (rice) is in november. No additional water is required for Amon (rice) is in july.

Crop water requirement from 1985 to 2015 in Barind area Rajshahi for Boro (rice) for average temperature is $423.6 \mathrm{~cm}$, for maximum temperature is $540.4 \mathrm{~cm}$ and for minimum temperature is $571.7 \mathrm{~cm}$. Maximum water requirement for Boro (rice) is in february. No additional water is required for Boro (rice) is in june.

Crop water requirement from 1985 to 2015 in Barind area Rajshahi for Wheat for average temperature is $164.9 \mathrm{~cm}$, for maximum temperature is $165.3 \mathrm{~cm}$ and for minimum temperature is $166.8 \mathrm{~cm}$. Maximum water requirement for Wheat is in November.

Crop water requirement from 1985 to 2015 in Barind area Rajshahi for Potato for average temperature is $167.7 \mathrm{~cm}$, for maximum temperature is $168 \mathrm{~cm}$ and for minimum temperature is $168.9 \mathrm{~cm}$. Maximum water requirement for Potato is in November.

Total Consumptive use from 1985 to 2015 in Barind area Rajshahi for average temperature for Amon(rice), Boro(rice), Wheat, Potato are $312.9 \mathrm{~cm}, 609.6 \mathrm{~cm}, 232.5 \mathrm{~cm}, 138.4 \mathrm{~cm}$ respectively. Total Consumptive use from 1985 to 2015 in Barind area Rajshahi for maximum temperature for Amon(rice), Boro(rice), Wheat, Potato are $1345.8 \mathrm{~cm}, 2868.1 \mathrm{~cm}, 1276 \mathrm{~cm}, 810.5 \mathrm{~cm}$ respectively.

Total Consumptive use from 1985 to 2015 in Barind area Rajshahi for minimum temperature for

Amon(rice), Boro(rice), Wheat, Potato are $1123.2 \mathrm{~cm}, 2095.5 \mathrm{~cm}$, $871.2 \mathrm{~cm}, 553.6 \mathrm{~cm}$ respectively.

\section{CONCLUSION}

Total irrigation requirement for the crops Amon, Boro, Potato and Wheat were determined. From calculation it is seen that maximum irrigation water is required in the month of April and groundwater extraction is more due to less rainfall and no additional water is required in the month of June and groundwater recharge is more due to excessive rainfall for rice. The maximum irrigation water is required for Potato crops in the month of January and groundwater extraction is more due to less rainfall and continuous water is to be supplied for the base period. For Wheat crops the maximum irrigation water required in the month of December to January and groundwater extraction is more due to less rainfall and continuous water has to be supplied for its base period. This conclusion can be drawn for aa crops that are included in this study.

\section{REFERENCES}

[1] DAS KUMAR SUMON (2007)- M.Sc thesis on "study of irrigation efficiencies and crop water requirement in various crops under barind area, BUET, DHAKA 1000

[2] SARMA, S.K.(1984)- "Principle and practice of irrigation engineering, S. Chand And Company Ltd. Ram Nagar, New Delhi-110055.

[3] Dhamge, M.N.R, Badar, A.M and Baiswarey, N.Z (2008)- crop water requirement by modified penman method using Hymos. The Indian Society for Hydraulics (ISH), Volume-14, Issue-3, pp. 28-42.

[4] Israelsen, W. O. and others (1962)-Irrigation Principles and practice. John Weilly and Sons, Inc, New York, London, Sydney.

[5] Rahman Azizur Md (2006)-M.Sc. thesis on estimation of potential recharge and ground water resources. A case study in low Barind area, Bangladesh University Applied Sciences Cologne, Germany. 
[6] Michael, A.M. (1978)-Irrigation Theory and Practice, vikas publishing house (P) Ltd 57G, Masjid road, Jangpura, New Delhi-110014.

[7] Raghunath, H.M. (1985) - Hydrology, principle, analysis, design. New age international Ltd. New Delhi-110002.

[8] Modi, P.N. (1988)-Irrigation Water Resources and Water Power Engineering, Standard Book House, 1705-4 Nai sarak, Delhi-110006

[9] Mahmud, N.N. (1996)-M.Sc. thesis on irrigation requirement of various crops under G-K project.

[10] Shiferaw, B.A, Wani, S.P and Rao, G.D.N (2003)- Irrigation investments and groundwater depletion in Indian semi-arid villages: the effect of alternaive water.

[11] Terrell. B.L and Johnson, P.N (1994) worked on- Economics impact of the Ogallala aquifer: a case study of the southern plains of Texas

[12] Liamas, M.R and Santos, P.M (2003) worked on- Intensive Ground water use: Salient Revolution and potential source of social conflict

[13] Garg, S.K. (1976)-Irrigation Engineering and Hydraulic Structure, Khanna publishers, 28, Nath Market, Nai Sarak, Delhi-110006

[14] Rahman, M.s(2004) worked on -study of irrigation by groung water in barind area, Rajshahi Barind Department, Rajshahi

[15] Khan, M.A.A and Pramanik,M.M.I (1995) worked on- Study of different water distribution system in irrigation project.

[16] Habib, M.A(2001) worked on - Evaluation of ground water potentially in Barind area (Godagari thana) Rajshahi.

[17] Reddi, P.J. (1986)-A text book of hydrology, Laxmi publications (P) Ltd. New Delhi11002

Website: en.wikipedia.org

[18] Lambers H 2003. Dry land salinity: A key environmental issue in southern AustraliaIntroduction. Plant Soil 257: VVii

[19] Munns R., 2005. Genes and salt tolerance: bringing them together. New Phytol 167: 645-63

[20] Qadir M, A Tubeileh, J Akhtar,ALarbi, PS Minhas, MA Khan 2008.Productivity enhancement of salt-affected environments through crop diversification. Land Degradation Development. 19:429-453

[21] Rozema J and TJ Flowers, 2008.Crops for a salinized world Science 322:1478-1480

[22] Munns, R., 2009: Strategies for crop improvement in saline soils. In: M. Ashraf, M. Ozturk, and H. R. Athar, eds. Salinity and Water Stress: Improving Crop Efficiency, pp. 99-110. Springer, The Netherlands. 